\title{
Biological responses to a resumption in river flow in a freshwater- deprived, permanently open Southern African estuary
}

\author{
Paul D Vorwerk', P William Froneman², Angus W Paterson'1, Nadine A Strydom ${ }^{3}$ and Alan K Whitfield ${ }^{3 *}$ \\ ${ }^{1}$ South African Environmental Observation Network (SAEON) Elwandle Node, Private Bag 1015, Grahamstown 6140, South Africa \\ ${ }^{2}$ Department of Zoology and Entomology, Rhodes University, Grahamstown 6140, South Africa \\ ${ }^{3}$ South African Institute for Aquatic Biodiversity (SAIAB), Private Bag 1015, Grahamstown 6140, South Africa
}

\begin{abstract}
The Kariega Estuary is a freshwater-deprived system due to numerous impoundments in the catchment. This system has had little or no horizontal salinity gradient over the last 15 years, with hypersaline conditions sometimes predominating in the upper reaches. Following high rainfall events in the catchment during the spring of 2006, including a flood event (approximate 1:10 year) in August 2006, a series of riverine pulses entered the estuary and a horizontal salinity gradient was established. This study examined the influence of this freshwater pulse on four components of the biota within the estuary, namely the zooplankton, and larval, littoral and demersal fishes. The study demonstrated that in three of these components elevated densities were recorded following the riverine input, with only the littoral fishes retaining an almost constant density. In addition, changes in the relative contributions of the estuarine utilisation classes for all three fish groups examined indicated that freshwater input into these systems positively influences the abundances. This has significant implications for water managers as it demonstrates the importance of an Ecological Reserve (defined as 'the water required to protect the aquatic ecosystems of the water resource') for this system.
\end{abstract}

Keywords: biotic response, freshwater pulse, river inflow, Kariega Estuary

\section{Introduction}

South Africa has a semi-arid climate with the average precipitation being $497 \mathrm{~mm}$ compared to the world average of $860 \mathrm{~mm}$ (DWAF, 1986). This, in addition to growth of the South African economy, has led to increased demand for freshwater which has resulted in the establishment of impoundments for the retention of surface water resources (DWAF, 2004; Jezewski and Roberts, 1986). Additional freshwater loss occurs in the form of invasive alien trees which have been reported to negatively impact flow volumes from river catchments (DWAF, 2004). The various forms of water usage have modified the river flow patterns entering estuarine ecosystems. Base flows into estuaries are often considerably reduced or removed altogether, while minor flood events may be entirely removed or considerably attenuated, depending on various factors (Davies and Day, 1986). These factors include the magnitude of the flood event, available storage capacity in impoundments, and the proximity of the impoundments to the head of the estuary (Davies et al., 1993; Davies and Day, 1986).

Several summary publications exist in the South African scientific literature describing the effects of freshwater deprivation on estuaries (e.g. Grange et al., 2000; Whitfield and Bruton, 1989; Whitfield and Wooldridge, 1994). These effects include reduced nutrient input, lack of salinity gradients and a reduction in land-based olfactory cues entering the coastal environment, all of which affect the biology in these systems. A number of studies have demonstrated that natural river flow variations are required to allow estuarine biotic communities to function opti-

\footnotetext{
To whom all correspondence should be addressed

e-mail: a.whitfield@ru.ac.za
}

mally (Froneman, 2002; Garcia et al., 2003; Kibirige et al., 2006; Ter Morshuizen et al., 1996). Indeed, recent research has demonstrated strong links between freshwater flow volumes entering estuaries and the biota in the adjacent near-shore environment (Vorwerk, 2006).

The Kariega Estuary is a freshwater-deprived Eastern Cape system, primarily due to numerous impoundments within its relatively small catchment. Monthly rainfall in the Port Alfred region ranged between $0 \mathrm{~mm} \cdot \mathrm{month}^{-1}$ and $149 \mathrm{~mm} \cdot \mathrm{month}^{-1}$ for the period 1 January 1995 to 31 December 2005, with only 3 months exceeding $90 \mathrm{~mm} \cdot$ month $^{-1}$ during this period. Higherthan-average rainfall was recorded in August and September $2006\left(205 \mathrm{~mm} \cdot \mathrm{month}^{-1}\right)$ in the Eastern Cape that has resulted in comparatively large river volumes in all estuaries along the coastline. In the Kariega Estuary the high rainfall led to the establishment of a horizontal salinity gradient in the system for the first time in 15 years (Allanson and Read, 1995; Ter Morshuizen and Whitfield, 1994; Vorwerk, 2006; Whitfield and Paterson, 2003). A combined study was initiated between researchers at Rhodes University, the South African Institute for Aquatic Biodiversity and the Elwandle Node of the South African Environmental Observation Network to establish the impact of this freshwater pulse on the biology of selected components in the Kariega Estuary. The biota were sampled shortly after the freshwater pulse in 2006 and compared to those recorded under modified low-flow conditions in 1991, 1996, 1999 and 2005.

\section{Materials and methods}

\section{Study area}

The Kariega Estuary (Fig. 1) is a marine-dominated, permanently open system on the south-east coast of South Africa 


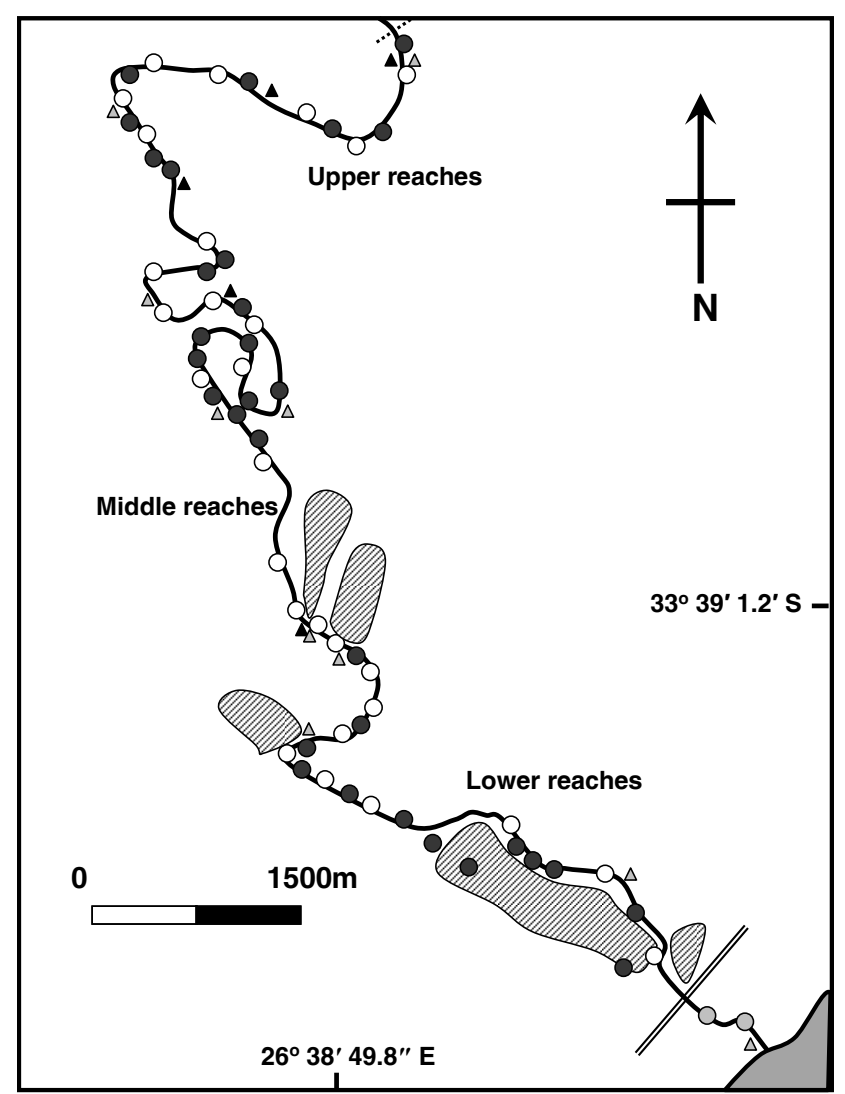

Figure 1

The Kariega Estuary, showing salt marsh areas along the length of the estuary (hatched shapes) and the head of the estuary at the constructed causeway (dotted line). Dark circles represent seine stations for the littoral fish study only (some were located on creeks in the lower reaches), while white circles represent stations occupied during both the littoral and demersal fish surveys. Light grey circles represent survey stations for the demersal fish survey only. Dark triangles represent the larval fish stations while light triangles represent the zooplankton sampling stations.

( $33^{\circ} 40^{\prime} 46.6^{\prime \prime} \mathrm{S} ; 26^{\circ} 40^{\prime} 57.9^{\prime \prime} \mathrm{E}$ ) (Whitfield, 2000). The marinedominated nature of the estuary arises due to several impoundments within its catchment that have restricted river flow to such an extent that the ratio of tidal prism volume to river volume is 106:1 (Grange et al., 2000). Restricted freshwater inputs have resulted in marine or hypersaline conditions being recorded in the upper reaches since 1991 (Allanson and Read, 1995; Strydom et al., 2003; Ter Morshuizen and Whitfield, 1994; Vorwerk, 2006; Whitfield and Paterson, 2003). The estuary is approximately $18 \mathrm{~km}$ long and varies between $40 \mathrm{~m}$ and $100 \mathrm{~m}$ in width, with an average channel depth of $2.5 \mathrm{~m}$ to $3.5 \mathrm{~m}$ (Bate et al., 2002; Bate and Adams, 2000). The sampling dates are indicated below for each biotic component.

\section{Chlorophyll a}

Total chlorophyll $a$ concentration for the surface and bottom waters was calculated from $200 \mathrm{~m} \ell$ water samples collected at the time of zooplankton sampling. Chlorophyll $a$ was determined according to the method of Holm-Hansen and Riemann (1978) by filtering the samples through $\mathrm{GF} / \mathrm{F}$ filters $(<5 \mathrm{~mm} \mathrm{Hg})$, before extraction in $90 \%$ acetone for $24 \mathrm{~h}$ at $-20^{\circ} \mathrm{C}$. An A10 AUTurner fluorometer was then used to measure the chlorophyll $a$ before and after acidification.

\section{Zooplankton}

Zooplankton were collected nocturnally from 10 stations along the length of the Kariega Estuary (for station localities see Fig. 1) in three replicate tows using a WP2 net $(100 \mu \mathrm{m}$ mesh) fitted with a General Oceanics Flow Meter. All samples were stored in $10 \%$ buffered formalin for later counting in the laboratory. Zooplankton density is expressed as a mean of three replicate samples and is presented as individuals $\mathrm{m}^{-3}$.

Surface temperature and salinity were measured at each site at the time of sampling, with temperatures expressed in degrees Centigrade $\left({ }^{\circ} \mathrm{C}\right)$ and salinity in terms of practical salinity units (PSU). Low flow data were collected in November 2005 while high flow data were collected in November 2006.

A Horiba U10 water sampler was used to determine the salinity and temperature conditions for all biotic components during the high flow (2006) sampling, while a hand-held thermometer and optical refractometer were used during all the low-flow samples (except for larval fishes where a YSI multi-parameter probe was used during both the high- and low-flow periods).

\section{Larval fish}

Two replicate surface tows were conducted at five stations in the middle and upper reaches of the Kariega Estuary using WP2 plankton nets (57 $\mathrm{cm}$ mouth diameter, $500 \mu \mathrm{m}$ mesh) with calibrated flow meters. The nets were fitted to a boom on the bow of a small boat and sampling was conducted after nightfall around new moon. The tows were conducted at a speed of 1 to 2 knots and were $3 \mathrm{~min}$ in duration. All samples were stored in $10 \%$ buffered formalin for later identification and counting in the laboratory. The low-flow data were collected in January 1999, while the high- flow data were collected in November 2006. Salinity and temperature at each station were determined in situ and expressed in the units outlined above.

\section{Demersal fish}

The demersal fishes were collected using an otter trawl at 30 stations along the length of the Kariega Estuary (see Fig. 1 for station localities). The otter trawl had a $2 \mathrm{~m}$ mouth width with a $6 \mathrm{~mm}$ stretch mesh net. Tows covered a distance of $100 \mathrm{~m}$ at a speed of approximately 2 knots. All fish were stored in $10 \%$ formalin for later identification and measuring in the laboratory. Low-flow sampling was conducted in November 1996, while the high flow survey was undertaken in November 2006. Water temperature and salinity at each station were measured at the time of sampling at the bottom of the water column. The fish catch per unit effort and water quality parameters were averaged across three adjacent stations for comparative purposes with the other data sets.

\section{Littoral fish}

Fish sampling occurred at 60 littoral stations (for locations see Fig. 1), mainly in Zostera beds, along the length of the Kariega Estuary using a $5 \mathrm{mx} 1 \mathrm{~m}$ fry seine net $(0.5 \mathrm{~mm}$ bar mesh). Sampling was conducted during daylight between mid-water spring and low water neap tides, which ensured that no transitory or pelagic species were in the Zostera beds. All fish were identified, measured and counted. The first survey was conducted in November 1991 which corresponds to a typical period of impounded river flow for the Kariega Estuary (low or zero flow), while the high flow survey took place in November 2006. 


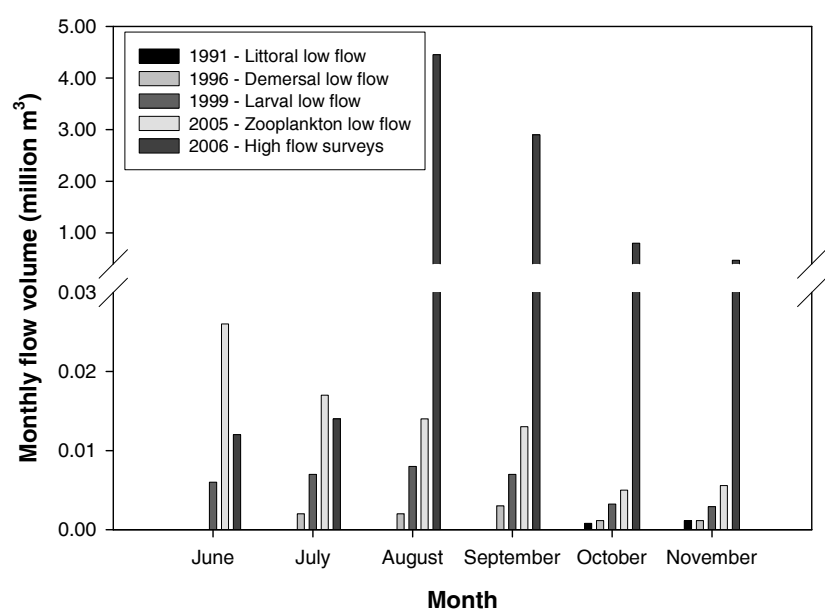

Figure 2

River discharge rates in the months preceding the sampling periods for each of the high- and low-flow surveys (Department of Water Affairs and Forestry unpublished flow-gauge data)

Temperature and salinity were determined in situ from midwater within the littoral zone. The water quality parameters and fish densities were averaged across 6 stations to enable comparison between data sets.

\section{Statistical analyses}

All statistical analyses were conducted using the STATISTICA software package (Statsoft Inc., 2004). To compare high and low flow volumes, salinity values, Chlorophyll $a$ concentrations and biotic densities, a one-way analysis of variance (ANOVA) was employed. Prior confirmation that the data was normally distributed was undertaken using a Lilliefors test for normality and homogeneity of variance was tested using Levene's Test. Where appropriate, non-parametric tests were used. A Spearman rank correlation was utilised to compare salinity for each sampling period relative to the flow volumes. For comparative purposes the fish caught during the larval, demersal and littoral fish surveys were categorised according to the estuary-association categories presented in Whitfield (1998).

\section{Results}

\section{Flow volumes}

The monthly river flow in the four months preceding all lowflow surveys did not exceed $0.026 \times 10^{6} \mathrm{~m}^{3}$ (Fig. 2). During the high flow period, flow volumes were significantly higher than those recorded during the low flow period $(\mathrm{P}=0.002 ; \mathrm{F}=13.31)$. In all of the four months prior to the November 2006 surveys (high flow), the flow volumes exceeded $0.01 \times 10^{6} \mathrm{~m}^{3}$, increasing from a minimum of $0.012 \times 10^{6} \mathrm{~m}^{3}$ in June to $4.45 \times 10^{6} \mathrm{~m}^{3}$ and $2.9 \times 10^{6} \mathrm{~m}^{3}$ in August and September, respectively (Fig. 2). This represents an increase of approximately three orders of magnitude from the late winter (August-September) prior to the low flow period to the late winter prior to the high flow period.

\section{Physico-chemical parameters}

The recorded water temperatures during each of the four studies demonstrated differences of up to $10^{\circ} \mathrm{C}$ (Fig. 3). During the zooplankton and littoral fish surveys the temperatures were similar
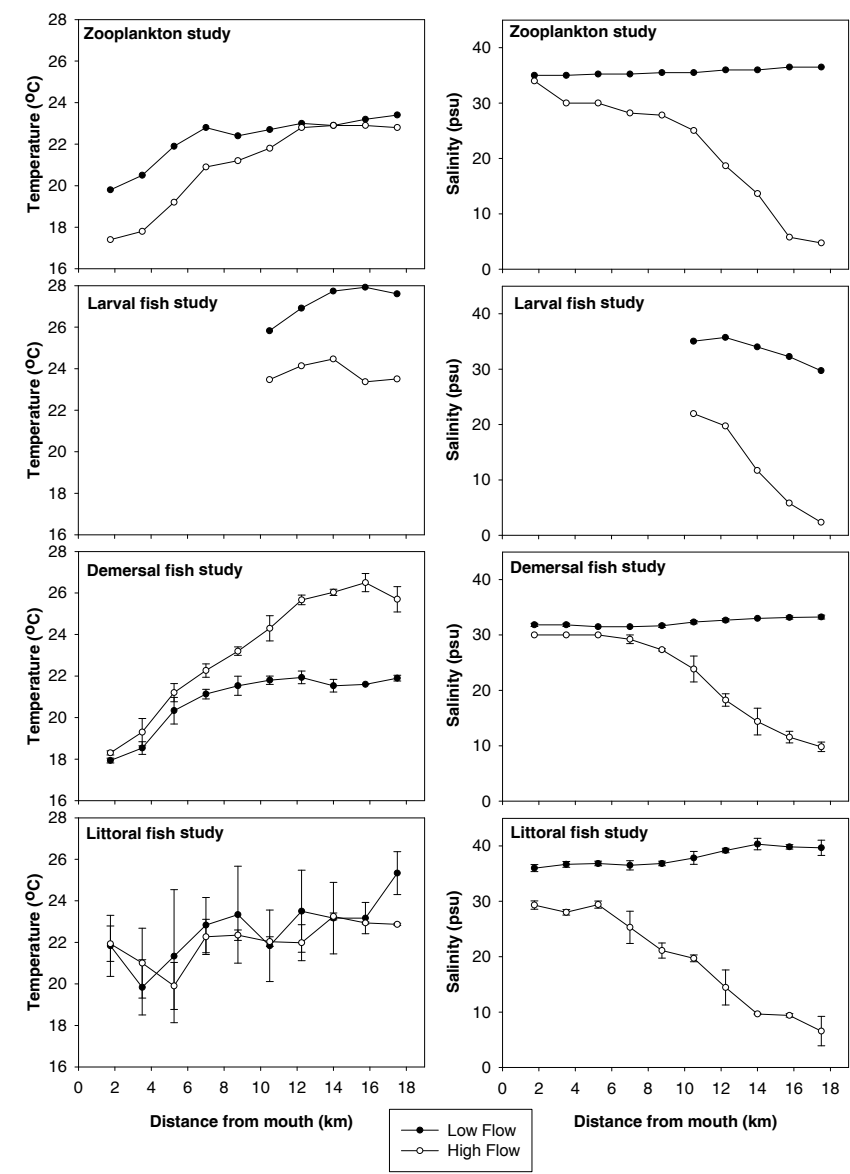

Figure 3

Temperature and salinity profiles during each survey. The demersal and littoral fish data points represent means of 3 and 6 sites, respectively, with error bars representing standard deviations.

TABLE 1

The significance levels and F-values for the ANOVA run on salinity during the various surveys and the biotic densities and chlorophyll concentrations. Significant values are indicated with an asterisk. The salinity samples for chlorophyll and zooplankton were recorded together.

\begin{tabular}{|l|c|c|c|c|}
\hline \multirow{2}{*}{ Study } & \multicolumn{2}{|c|}{ ANOVA on salinity } & \multicolumn{2}{c|}{$\begin{array}{c}\text { ANOVA on densityl } \\
\text { concentration }\end{array}$} \\
\cline { 2 - 5 } & P-value & F-statistic & P-value & F-statistic \\
\hline Chlorophyll & $<0.001^{*}$ & 17.31 & $0.001^{*}$ & 15.21 \\
\cline { 1 - 3 } Zooplankton & & & $0.02^{*}$ & 6.39 \\
\hline Larval fish & $<0.001^{*}$ & 28.24 & 0.50 & 0.50 \\
\hline Demersal fish & $0.001^{*}$ & 14.31 & $0.002^{*}$ & 12.50 \\
\hline Littoral fish & $<0.001^{*}$ & 43.70 & 0.20 & 1.76 \\
\hline
\end{tabular}

between the years, although a difference was recorded in the lower reaches for the zooplankton survey. During the larval and demersal fish surveys, a deviation between the years was apparent in the upper reaches, with the low flow period recording higher temperatures during the larval fish survey and the high flow period reporting higher temperatures during the demersal fish survey (Fig. 3).

The salinity during all the low flow period surveys demonstrated a significantly higher profile relative to the elevated flow period (Table 1, Fig. 3). All the high flow surveys indicated a horizontal salinity gradient, with higher salinities (range: 29.5 -35 ) recorded in the lower reaches and lower salinity values in 


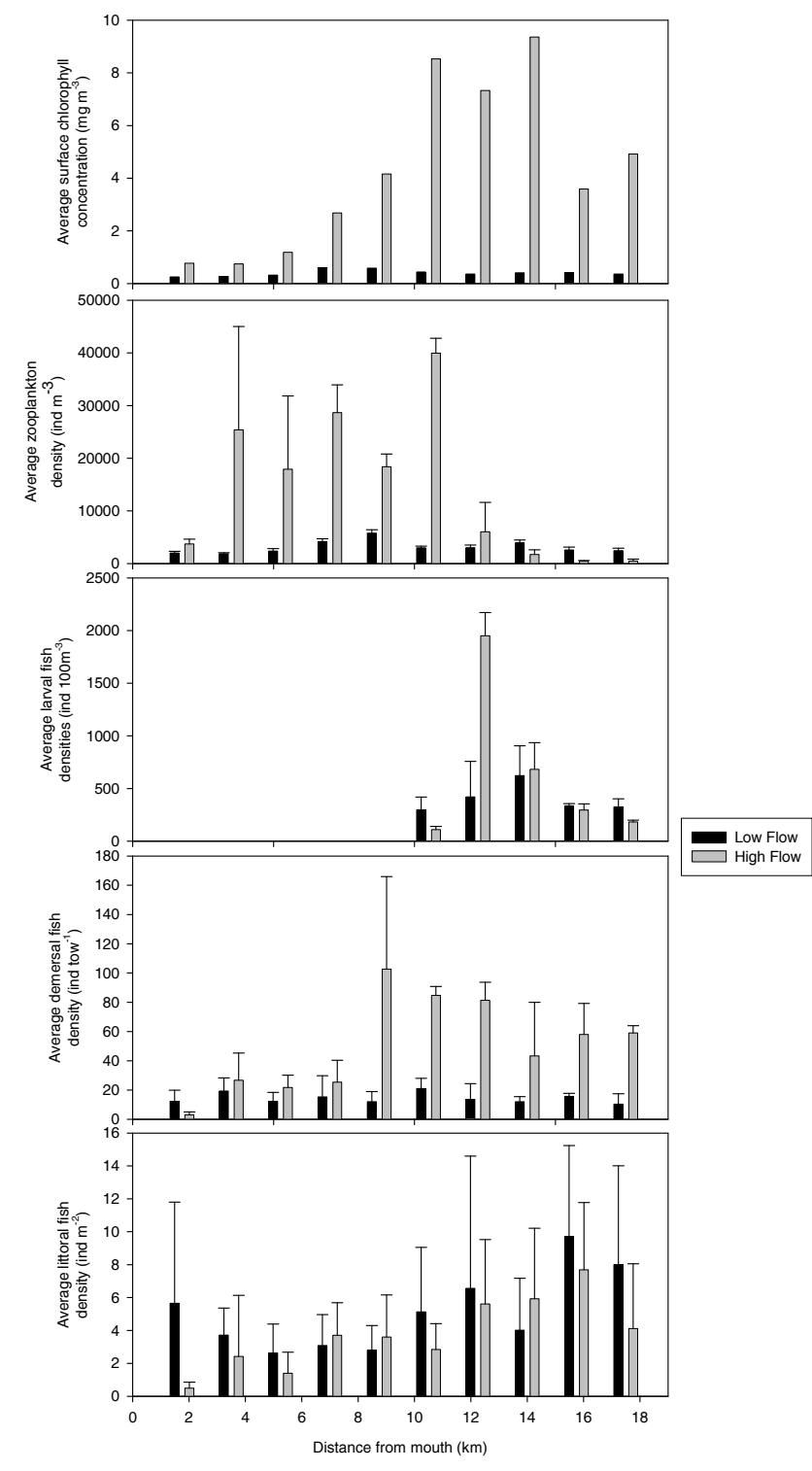

Figure 4

Longitudinal trends in the densities of selected biotic components within the Kariega Estuary during both low- and high-flow periods. Zooplankton density is the mean of 3 replicate tows while the larval fish densities are the mean of 2 replicate tows. Demersal fish densities are the mean across 3 adjacent sites and the littoral densities are the mean across 6 adjacent sites. Error bars represent the standard deviations.

the upper reaches (range: 2.3-9.8). The low flow salinity was always close to marine water (35), with the minimum recorded salinity being 29.7 and the maximum being hypersaline at 40.3 (Fig. 3). The slightly depressed salinity values recorded in the upper reaches during the low flow period larval fish survey corresponded to moderate river flow rates in the months preceding this particular sampling (Fig. 2). Overall, the recorded salinities demonstrated a significant negative correlation with the reported monthly river flow volumes $(\mathrm{P}<0.05 ; \mathrm{R}=0.84)$.

\section{Biological parameters}

\section{Chlorophyll a concentration}

The total surface Chlorophyll $a$ concentrations recorded during the high and low flow periods demonstrated very different longitudinal trends (Fig. 4). The total chlorophyll concentration recorded during the low flow period was uniformly low throughout the estuary (0.25-0.6 $\left.\mu \mathrm{g} \ell^{-1}\right)$. The high flow chlorophyll concentrations were significantly higher than those recorded during the low flow period (Table $1, \mathrm{P}=0.001 ; \mathrm{F}=15.21$ ) and demonstrated an increasing longitudinal trend, with the minimum at the mouth $\left(0.74 \mu \mathrm{g} \ell^{-1}\right)$ and the maximum $\left(9.36 \mu \mathrm{g} \ell^{-1}\right)$ recorded in the upper reaches of the estuary (Fig. 4).

\section{Zooplankton density}

The zooplankton densities recorded during the low flow period ranged between 1864 individuals $\mathrm{m}^{-3}$ and 5780 individuals $\mathrm{m}^{-3}$ (Fig. 4). The high flow zooplankton densities were significantly higher than those recorded during the low flow period (Table 1: $\mathrm{P}$ $=0.02 ; \mathrm{F}=6.39$ ), with most values exceeding 18000 individuals $\mathrm{m}^{-3}$ in the lower and middle reaches of the estuary (Fig. 4).

\section{Larval fish density}

Similar mean larval fish densities were recorded in the surface waters of the middle and upper reaches of the Kariega Estuary during the high and low flow periods. The range of densities observed for larval fishes was greater during the high flow period. In particular, densities $12 \mathrm{~km}$ upstream from the mouth in the high flow period were four times greater than during the low flow period (Fig. 4). Larval fish densities recorded during the low flow period ranged between 297 and 623 individuals 100 $\mathrm{m}^{-3}$, while the high flow densities ranged from 110 to 1950 individuals $100 \mathrm{~m}^{-3}$.

\section{Demersal fish catch per unit effort (CPUE)}

The demersal fish demonstrated a significantly higher CPUE during the high flow period relative to the low flow (Table 1: $\mathrm{P}$ $=0.002 ; \mathrm{F}=12.50$ ). Almost uniform demersal fish CPUE was recorded throughout the estuary during the low flow period, with densities ranging from 10-21 individuals tow ${ }^{-1}$. Conversely, during the high flow period a longitudinal pattern emerged, with the lower reaches stations having reduced CPUE (3-27 individuals tow $\left.^{-1}\right)$ relative to those recorded in the middle and upper reaches (43.3 - 102.7 individuals tow ${ }^{-1}$ ) (Fig. 4).

\section{Littoral fish density}

No significant differences were evident in the littoral fish densities between the low and high flow periods (Table 1: $\mathrm{P}>0.05$ ). The densities recorded during the low flow period ranged from 2.6-9.7 individuals $\mathrm{m}^{-2}$, while those recorded during the high flow period ranged between 0.5 and 7.7 individuals $\mathrm{m}^{-2}$ (Fig. 4). Both periods demonstrated a longitudinal trend in littoral fish abundance with slightly elevated densities in the upper reaches of the estuary (Fig. 4).

\section{Estuarine utilisation category contributions to fish catches}

Shifts in estuarine utilisation categories amongst fishes were observed in the estuary between wet and dry years. The contribution of both category I (estuarine residents) and category II (estuarine dependent marine) species to the total larval fish densities increased from the low to high flow periods (Fig. 5). Similarly, the number of larval fish species from both category I and II increased from the low to high flow periods, although the net increase in category II species was greater than category I species. Similarly, the number of demersal fish species in all represented categories (I, II and III) increased from the low to high flow periods (Fig. 5). The trend in demersal fish CPUE in each estuarine utilisation category was reversed from low to 


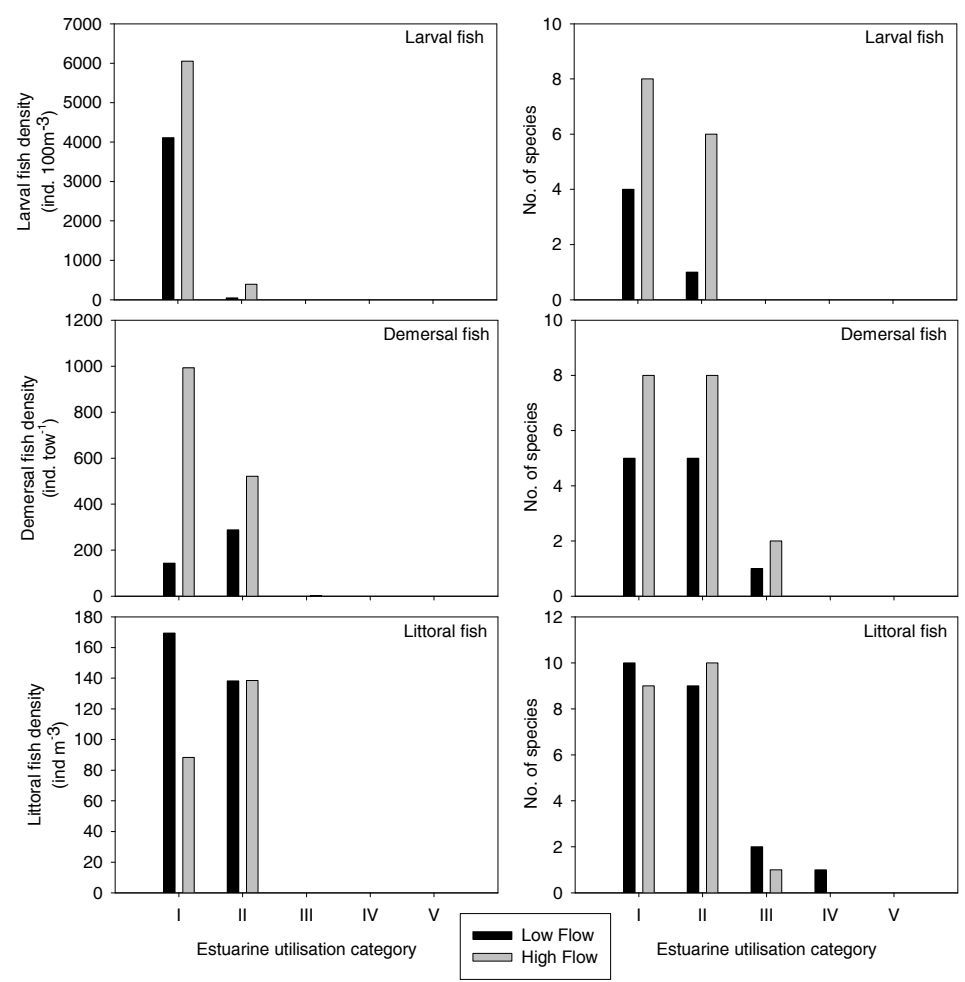

Figure 5

The density and number of species per estuarine utilisation category (after Whitfield, 1998) from each of the larval, demersal and littoral fish studies

high flow, with estuarine dependent marine species dominating during the low flow period, and higher CPUE of estuarine resident species during the high flow period (Fig. 5). The littoral fish densities and species numbers were greater in all categories during the low flow period relative to the high flow period, with the only exceptions being identical densities and an additional species in category II during the high flow period (Fig. 5).

\section{Discussion}

\section{Freshwater flow and biological interactions}

The significant negative correlation between the mean salinity reported during surveys and the flow volumes highlights the fact that salinities are highly dependent on riverine flow volumes as demonstrated previously by several authors (e.g. Armor and Herrgesell, 1985; Bate et al., 2002; Grange et al., 2000; Grange and Allanson, 1995; Read, 1983). However, the formation of a horizontal salinity gradient is of more importance, as it infers an increase in available niches to biota within the estuary. The movement of horizontal gradients along the estuary depending on river flow is an acknowledged trend and is associated with the river-estuary-interface (REI) region (Bate et al., 2002). The REI is an important mixing zone in South African estuaries and has been identified as that region with an integrated vertical salinity of $<10$. The REI has been associated with higher phytoplankton production and zooplankton biomass and densities (Bate et al., 2002).

The results of this study indicate that highest Chlorophyll $a$ concentrations were recorded in the REI region (salinity $<10 \mathrm{PSU}$ ) during the high flow period, but the maximum high flow chlorophyll concentrations were recorded in the mesohaline (10-15 PSU) region just downstream of the REI. This may reflect water movement in a downstream direction, carrying the chlorophyll production towards the estuary mouth in the process. Higher chlorophyll concentrations have traditionally been associated with increased river flow volumes due to imported chlorophyll from the riverine environment, or increased in situ production due to imported nutrients (Grange and Allanson, 1995; Nozias et al., 2001).

Significantly greater zooplankton and demersal fish densities were reported for the high flow relative to the low flow period, despite only three months having passed since the onset of higher river flow into the estuary. Several authors have reported increased zooplankton density and biomass associated with higher river flow volumes (e.g. Froneman, 2002; Grange et al., 2000; Schlacher and Wooldridge, 1996). Grange et al. (2000) and Wooldridge (1999) have linked increased zooplankton density to increased food resources (mainly phytoplankton) as a result of elevated freshwater inflow, but have also reported that zooplankton distributions are influenced by salinity and temperature regimes. The maximum zooplankton densities during this study only slightly overlapped with the maximum chlorophyll concentrations, and were concentrated in the lower to middle reaches of the estuary where salinities were polyhaline (salinity 18-30). The possibility exists that zooplankton in these areas were feeding on both phytoplankton and particulate organic matter transported into the region by increased river flow (Jerling and Wooldridge, 1995a).

The maximum demersal fish CPUE occurred in the middle and upper reaches of the estuary during the high flow period (Fig. 4). The maximum CPUE in the upper reaches is primarily due to the dominance of estuarine resident species (Fig. 5), with Glossogobius callidus accounting for more than $50 \%$ of the total fishes sampled during the high flow period. Despite being considered as an estuarine resident in the Whitfield (1998) classification system, Glossogobius callidus also occurs in river systems (Skelton, 2001) and the increased abundance of this species in the Kariega Estuary may be a function of individuals being washed into the system from the adjacent catchment during river flooding.

It is interesting to note that absolute larval and littoral fish densities did not differ significantly between the low and high flow periods. The lack of a response in the littoral zone is likely due to a longer response time required for the species associated with these areas to recruit into the estuary (Whitfield, 1998). Similarly, in terms of the larval fishes, the catches were dominated by estuarine resident species during both high and low flow periods. However, the increase in the number of estuarine dependent marine species represented in the larval fish catches demonstrates an increase in recruitment into the estuary from the adjacent marine environment, possibly as a result of increased olfactory cues entering the coastal zone (Strydom, 2003). Larval fishes may also be targeting a low salinity nursery at the head of the estuary, where many predators are excluded. This phenomenon is not well studied, but larvae of marine fishes are regularly encountered in low salinity water in the extreme upper reaches of warm temperate estuaries (Strydom et al., 2003). Increased recruitment is also indicated by the increased dominance of estuarine-dependent marine species in the littoral fish survey during the high-flow period (Fig. 5). James et al. (2008) have demonstrated, using laboratory 
trials, that larval Rhabdosargus holubi respond positively to olfactory cues related to both estuarine and freshwater sources.

The return of the pipefish Syngnathus watermeyeri to the Kariega Estuary after local extinction in the 1980s and 1990s was also an important indicator of environmental change. The local extinction of this species was suggested to be due to reductions in its zooplankton food source, especially for the juveniles of this species which rely on the small size classes of zooplankton (microzooplankters) that predominate following periods of increased river flow (Whitfield, 1995; Whitfield and Bruton, 1996). The return of this species following two months of elevated riverine input (Fig. 2) reinforces the reliance of this species on freshwater pulses for successful recolonisation and reproduction within this ecosystem (Vorwerk et al., 2007).

\section{Management implications}

The results from this study emphasize the effect that freshwater inflow has on selected physico-chemical variables and the biota within a permanently open estuary. The measured change in salinity was significant from the low- to high-flow periods, with the formation of a strong horizontal salinity gradient during higher river flow conditions. Other associated variables were not measured but their effects can be seen in the biotic components of the estuary, namely increased nutrient and autochthonous primary production as well as increased allochthonous input from the river. The increase in nutrients or imported chlorophyll can be inferred from the significantly higher chlorophyll concentrations measured during the higher river flow conditions, while an increase in allochthonous input (particulate organic matter) may have resulted from the higher densities of zooplankton recorded during the high flow study.

The influence of freshwater inflow in structuring estuarine ichthyofaunal and zooplankton communities has been documented in a number of local and international studies (e.g. Armor and Herrgesell, 1985; Bate et al., 2002; Gillanders and Kingsford, 2002; Jerling and Wooldridge, 1995b; Paterson and Whitfield, 1997; Potter and Hyndes, 1994; Schlacher and Wooldridge, 1996; Strydom et al., 2002; Ter Morshuizen et al., 1996; Whitfield, 2005). Strydom et al. (2002) suggested that the required monthly flow rates for larval fishes are between 1 and $12 \times 10^{6} \mathrm{~m}^{3}$ dependent on the morphology of the estuarine system. It has been difficult to identify exactly how freshwater flow volumes influence the biotic communities within estuaries, and the current understanding is that freshwater inflow has secondary impacts on a number of environmental variables which in turn combine to alter communities within estuaries (Whitfield, 2005). The milieu of environmental factors influenced by freshwater inflow includes changes to estuarine morphometry, allochthonous inputs, turbidity, nutrient status, temperature, $\mathrm{pH}$, salinity and dissolved oxygen concentrations (Grange et al., 2000; Grange and Allanson, 1995; Whitfield, 2005; Whitfield and Wooldridge, 1994). Secondary environmental effects of freshwater inflow include alterations to the mouth status and tidal prism of estuaries, increased habitat diversity, and primary and secondary production (Grange and Allanson, 1995; Perissinotto et al., 2003; Schlacher and Wooldridge, 1996; Whitfield, 2005).

In South Africa, due to the arid nature of the country, water entering estuaries and the marine environment has for a long time been considered a waste of a valuable resource (Burman, 1970; Morant and Quinn, 1999). This perception has recently changed, primarily due to the new National Water Act of 1998 (Act 36), which established the requirement that all river systems should have an Ecological Reserve amount (water quantity and quality) set aside; as the new act recognised that the environment was a legitimate and necessary water user. Both the river and estuary are considered as resources that must be protected as they provide goods and services. The Ecological Reserve relates to "the water required to protect the aquatic ecosystems of the water resource", including both rivers and estuaries.

Recent research has indicated that freshwater influences the productivity of the marine environment adjacent to estuaries, with increased biological productivity associated with estuaries with higher freshwater flow volumes (Vorwerk, 2006). Ecological Reserve determinations have already been completed for some South African systems (e.g. Adams et al., 2002) but many still require attention. There is also an increasing focus on the role that rivers and estuaries play in the functioning of coastal waters around South Africa, e.g. the Thukela Banks.

Considering the marked effect that an increase in flow volumes had on the zooplankton and fish resources within the Kariega Estuary and thus the health of the system, water managers should strongly consider establishing an Ecological Reserve for this and other similarly freshwater-deprived estuaries. When major dams on the Kariega and its tributary rivers were built more than three decades ago (Settlers Dam in 1962), a water release policy was instituted for downstream agriculture. However, no water allocation was provided for the environmental requirements of either the river or estuary and there is an urgent need to redress this oversight. An operating schedule allowing for the release of freshwater will likely result in positive changes for the estuary and encourage a resurgence of the aquatic biota in both the river and estuary.

Of particular importance is the re-establishment of what appears to be a breeding community of $S$. watermeyeri within the estuary, most likely due to the increased food resources available following the higher river flow volumes (Vorwerk et al., 2007). Should an Ecological Reserve be established for the Kariega, two crucial considerations would be the timing and flow volumes of future water releases from impoundments on this system. Timing is essential due to the potential effect of olfactory cues on recruitment of estuarine dependent marine species and any water releases should coincide with the spring peak in breeding and recruitment of estuarine dependent marine species (James et al., 2008; Strydom, 2003). The benefits of different flow volumes of any potential water releases would also have to be considered due to the potential scouring benefits of a single large release relative to a series of smaller releases (Baird and Heymans, 1996; Bate et al., 2002; Reddering and Rust, 1990).

\section{Acknowledgements}

The authors would like to thank the National Research Foundation (NRF) of South Africa and the South African Ecological Observation Network (SAEON) Elwandle Node for financial assistance during this study.

\section{References}

ADAMS JB, BATE GC, HARRISON TD, HUIZINGA P, TALJAARD $S$, VAN NIEKERK L, PLUMSTEAD EE, WHITFIELD AK and WOOLDRIDGE TH (2002) A method to assess the freshwater inflow requirements of estuaries and application to the Mtata Estuary, South Africa. Estuaries 25 1382-1393.

ALLANSON BR and READ GHL (1995) Further comment on the response of Eastern Cape Province estuaries to variable freshwater inflows. S. Afr. J. Aquat. Sci. 21 56-70. 
ARMOR C and HERRGESELL PL (1985) Distribution and abundance of fishes in the San Francisco Bay estuary between 1980 and 1982. Hydrobiol. 129 211-227.

BAIRD D and HEYMANS JJ (1996) Assessment of ecosystem changes in response to freshwater inflow of the Kromme River Estuary, St Francis Bay, South Africa: A network analysis approach. Water SA 22 (4) 307-318. http://www.wrc.org.za/downloads/watersa/1996 October/0945\%20abstract.pdf

BATE GC, WHITFIELD AK, ADAMS JB, HUIZINGA $P$ and WOOLDRIDGE TH (2002) The importance of the river-estuary interface (REI) zone in estuaries. Water SA 28 (3) 271-279. http:// Www.wrc.org.za/archives/watersa\%20archive/2002/July/1471.pdf

BATE GC and JB ADAMS (2000) The effects of a single freshwater release into the Kromme Estuary: Overview and interpretation for the future. Water $S A 26$ (3) 329-332. http://www.wrc.org.za/archives watersa\%20archive/2000/July/1301e.pdf

BURMAN J (1970) Waters of the Western Cape. Human \& Rousseau, Cape Town.

DAVIES B R and DAY J H (1986) The Biology and Ecology of South Africa's Vanishing Waters. University of Cape Town, Rondebosch, South Africa.

DAVIES BR, O'KEEFFE JH and SNADDON CD (1993) A Synthesis of the Ecological Functioning, Conservation And Management of South African River Ecosystems. WRC Report No. TT 62/93. Water Research Commission, Pretoria, South Africa.

DWAF, DEPARTMENT OF WATER AFFAIRS AND FORESTRY (1986) Management of the Water Resources of Southern Africa. Government Printer, Pretoria. 488 pp.

DWAF, DEPARTMENT OF WATER AFFAIRS AND FORESTRY (2004) National Water Resource Strategy. Department of Water Affairs and Forestry, Pretoria, South Africa. 150 pp.

FRONEMAN PW (2002) Response of the plankton to three different hydrological phases of the temporarily open/closed Kasouga Estuary, South Africa. Estuar. Coast. Shelf Sci. 55 535-546.

GARCIA AM, VIEIRA JP and WINEMILLER KO (2003) Effects of the 1997-1998 El Niño on the dynamics of the shallow-water fish assemblage of the Patos Lagoon estuary (Brazil). Estuar. Coast. Shelf Sci. $\mathbf{5 7}$ 489-500.

GILLANDERS BM and KINGSFORD MJ (2002) Impact of changes in flow of freshwater on estuarine and open coastal habitats and the associated organisms. Oceanogr. Mar. Biol. 40 233-309.

GRANGE N and ALLANSON BR (1995) The influence of freshwater inflow on the nature, amount and distribution of seston in estuaries of the Eastern Cape, South Africa. Estuar. Coast. Shelf Sci. $\mathbf{4 0}$ 403-420.

GRANGE N, WHITFIELD AK, DE VILLIERS CJ and ALLANSON BR (2000) The response of two South African east coast estuaries to altered river flow regimes. Aquat. Conserv.: Mar. Freshwater Ecosyst. 10 155-177.

HOLM-HANSEN O and RIEMANN B (1978) Chlorophyll- $a$ determination: improvements in methodology. Oikos 30 438-447.

JAMES NC, COWLEY PD, WHITFIELD AK and KAISER H (2008) Choice chamber experiments to test the attraction of postflexion Rhabdosargus holubi larvae to water of estuarine and riverine origin. Estuar. Coast. Shelf Sci. 77 143-149.

JERLING HL and WOOLDRIDGE TH (1995a) Plankton distribution and abundance in the Sundays River estuary, South Africa, with comments on potential feeding interactions. S. Afr. J. Mar. Sci. 15 169-184.

JERLING HL and WOOLDRIDGE TH (1995b) Relatively negative $\mathrm{d}^{13} \mathrm{C}$ ratios of mesozooplankton in the Sundays River estuary, comments on potential carbon sources. S. Afr. J. Aquat. Sci. 21 71-77.

JEZEWSKI WA and ROBERTS CPR (1986) Estuarine and Lake Freshwater Requirements. Department of Water Affairs Technical Report No. TR 129. DWAF, South Africa. 36 pp.

KIBIRIGE I, PERISSINOTTO R and THWALA X (2006) A comparative study of zooplankton dynamics in two subtropical temporarily open/closed estuaries, South Africa. Mar. Biol. 148 1307-1324.

MORANT PD and QUINN NW (1999) Influence of man and management of South African estuaries. In: Allanson BR and Baird D (eds.) Estuaries of South Africa. Cambridge University Press, Cambridge. 289-320.
NOZIAS C, PERISSINOTTO R and MUNDREE S (2001) Annual cycle of microalgal biomass in a South African temporarily-open estuary: nutrients versus light limitation. Mar. Ecol. Progress Series 223 39-48

PATERSON AW and WHITFIELD AK (1997) A stable carbon isotope study of the food-web in a freshwater-deprived South African estuary, with particular emphasis on the ichthyofauna. Estuar. Coast. Shelf Sci. 45 705-715.

PERISSINOTTO R, NOZIAS C, KIBIRIGE I and ANANDRAJ A (2003) Planktonic food webs and benthic-pelagic coupling in three South African temporarily-open estuaries. Acta Oecol. 24 S307-S316.

POTTER IC and HYNDES GA (1994) Composition of the fish fauna of a permanently open estuary on the southern coast of Australia, and comparisons with a nearby seasonally closed estuary. Mar. Biol. 121 199-209.

READ GHL (1983) The effect of a dry and wet summer on the thermal and salinity structure of the middle and upper reaches of the Keiskamma estuary, Ciskei. Trans. Royal Soc. S. Afr. 45 45-62.

REDDERING JSV and RUST IC (1990) Historical changes and sedimentary characteristics of southern African estuaries. S. Afr. J. Sci. 86 425-428.

SCHLACHER TA and WOOLDRIDGE TH (1996) Ecological responses to reductions in freshwater supply and quality in South Africa's estuaries: lessons for management and conservation. J. Coast. Conserv. 2 115-130.

SKELTON PH (2001) A Complete Guide to the Freshwater Fishes of Southern Africa. Struik, Cape Town, South Africa. 395 pp.

STATSOFT INC. (2004) STATISTICA (data analysis software system), Version 7.

STRYDOM NA (2003) Occurrence of larval and early juvenile fishes in the surf zone adjacent to two intermittently open estuaries, South Africa. Environ. Biol. Fish. 66 349-359.

STRYDOM NA, WHITFIELD AK and PATERSON AW (2002) Influence of altered freshwater flow regimes on abundance of larval and juvenile Gilchristella aestuaria (Pisces: Clupeidae) in the upper reaches of two South African estuaries. Mar. Freshwater Res. 53 431-438.

STRYDOM NA, WHITFIELD AK and WOOLDRIDGE TH (2003) The role of estuarine type in characterizing early stage fish assemblages in warm temperate estuaries, South Africa. Afr. Zool. 38 29-43.

TER MORSHUIZEN LD and WHITFIELD AK (1994) The distribution of littoral fish associated with eelgrass Zostera capensis in the Kariega estuary, a southern African system with a reversed salinity gradient. S. Afr. J. Mar. Sci. 14 95-105.

TER MORSHUIZEN LD, WHITFIELD AK and PATERSON AW (1996) Influence of freshwater flow regime on fish assemblages in the Great Fish River and estuary. S. Afr. J. Aquat. Sci. 22 52-61.

VORWERK PD (2006) A Preliminary Examination of Selected Biological Links Between Four Eastern Cape Estuaries and the Inshore Marine Environment. Ph.D. Thesis, Rhodes University, Grahamstown. 1-268.

VORWERK PD, FRONEMAN PW and PATERSON AW (2007) Revival of the critically endangered river pipefish, Syngnathus watermeyeri, in Eastern Cape estuaries. S. Afr. J. Sci. 103 199-201.

WHITFIELD AK (1995) Threatened fish of the world: Syngnathus watermeyeri Smith, 1963 (Syngnathidae). Environ. Biol. Fish. 44 152-152.

WHITFIELD AK (1998) Biology and Ecology of Fishes in Southern African Estuaries. Ichthyol. Monogr. of the JLB Smith Inst. of Ichthyol. 2 1-223.

WHITFIELD AK (2000) Available Scientific Information on Individual South African Estuarine Systems. WRC Report No. 577/3/00 1-137. Water Research Commission, Pretoria, South Africa.

WHITFIELD AK (2005) Fishes and freshwater in southern African estuaries - A review. Aquat. Living Resour. 18 275-289.

WHITFIELD AK and BRUTON MN (1989) Some biological implications of reduced fresh water inflow into eastern Cape estuaries: a preliminary assessment. S. Afr. J. Sci. 85 691-694.

WHITFIELD AK and BRUTON MN (1996) Extinction of the river pipefish Syngnathus watermeyeri in the Eastern Cape Province, South Africa. S. Afr. J. Zool. 92 59-61. 
WHITFIELD AK and PATERSON AW (2003) Distribution patterns of fishes in a freshwater deprived Eastern Cape estuary, with particular emphasis on the geographical headwater region. Water SA 29 (1) 61-67. http://www.wrc.org.za/archives/watersa\%20archive/2003/ anuary/11.pdf

WHITFIELD AK and WOOLDRIDGE TH (1994) Changes in freshwater supplies to southern African estuaries: some theoretical and practical considerations. In: Dyer KR and Orth RJ (eds.) Changes in Fluxes in Estuaries: Implications from Science to Management. Olsen \& Olsen, Fredensborg. 41-50.

WOOLDRIDGE TH (1999) Estuarine zooplankton community structure and dynamics. In: Allanson BR and Baird D (eds.) Estuaries of South Africa. Cambridge University Press, Cambridge. 141-166. 